\title{
Religion and Spirituality in the Life of Individuals with Paraplegia: Spiritual Journey from Trauma to Spiritual Development
}

\author{
Zeynep Şimşiri ${ }^{1}$ \\ Necmettin Erbakan \\ University
}

\author{
S. Tuba Boynueğri ${ }^{2}$ \\ İstanbul Sabahattin Zaim \\ University
}

\author{
Bülent Dilmaç3 \\ Necmettin Erbakan \\ University
}

Abstract

Traumatic experiences that leave deep traces on people's lives can lead to negative outcomes, as well as positive outcomes like maturation, growth and development. The experience known as post-traumatic growth is largely to result of one's religious and spiritual tendencies. At the same time, traumatic experiences can lead to changes in people's religious and spiritual lives. The aim of this research is to reveal the effects of paraplegic individuals' religious and spiritual tendencies on their post-traumatic growth and the changes that a traumatic experience causes in one's religious and spiritual life. The phenomenological design is used in research with a qualitative nature like this. Data were collected through interviews that were performed over 15 adults with spinal cord injuries. The obtained data were analyzed through the technique of content analysis. The themes that emerged from analysis are: ways of dealing with trauma, changes in attitudes towards God, religious practices, changes in belief in fate and an afterlife, religious participation. According to the research results, some individuals with spinal cord injuries benefit from religion and spirituality; a great majority overcome the situation by accepting it in order to cope with the traumatic experience. Many changes take place positively in these paraplegics' religious and spiritual lives in the aftermath of their traumatic experiences, strengthening their faith in what they believe in and their ties with God. This shows that after a traumatic experience, great changes can occur in one's religious and spiritual life.

Keywords

Post-traumatic growth $\bullet$ Spirituality $\bullet$ Religion $\bullet$ Paraplegia $\bullet$ Phenomenology

\section{Omurilik Felci Geçiren Bireylerin Yaşamında Din ve Maneviyat: Travma ile Başa Çıkmadan Travma Sonrası Manevi Gelişime Yolculuk}

$\ddot{\mathrm{O} z}$

İnsanların yaşamında derin izler bırakan travmatik deneyimler olumsuz sonuçlar doğurmasının yanı sıra olgunlaşma, büyüme ve gelişim olarak ifade edebileceğimiz olumlu sonuçlara da yol açabilmektedir. Travma sonrası gelişim olarak ifade edilen bu deneyimin gerçekleșmesinde insanların sahip olduğu dini ve manevi eğilimlerin rolü büyüktür. Aynı zamanda geçirilen travmatik deneyimler kişilerin dini ve manevi yaşantısında değişimlere sebep olabilmektedir. Bu araştırmanın amacı omurilik felci geçiren bireylerin dini ve manevi eğilimlerinin travma sonrası gelişim üzerindeki etkisini ve travmatik yaşantının dini ve manevi yaşantıda meydana getirdiği değișimleri ortaya koymaktır. Nitel bir doğaya sahip olan araștırmada fenomenoloji deseni kullanılmıștır. Veriler görüşme yöntemi ile toplanmış ve omurilik felci olan 15 yetişkinle görüşme yapılmıștır. Elde edilen veriler içerik analizi tekniği ile analiz edilmiştir. Analiz sonucunda ortaya çıkan temalar şunlardır: Travma ile başa çıkma yolları, Allah'a dair tutumlarda değişim, dini pratikler, ahiret ve kader inancında değissim, dini katılım. Araştırma sonuçlarına göre omurilik felçli bireylerden bazıları travma yaşantısı ile başa çıkmak için din ve maneviyattan faydalansa da çoğunluğu yaşadığı durumu kabullenerek başa çıkmıștır. Yaşanan olaydan sonraki süreçte ise felçli kişilerin dini ve manevi yaşantısında pozitif yönde pek çok değişim meydana gelmiş; inandıkları din ve Tanrıyla olan bağları güçlenmiştir. Bu durum bize travmatik deneyimlerin ardından dini ve manevi yaşantıda büyük değişimler meydana gelebileceğini göstermiştir.

\section{Anahtar Kelimeler}

Travma sonrası gelişim • Maneviyat • Din • Omurilik felci • Fenomenoloji

\footnotetext{
1 Correspondence to: Zeynep Şimşir, Department of Guidance and Psychological Counseling. Necmettin Erbakan University, Konya, Turkey. Email: zey.simsir.93@gmail.com

2 Department of Pre-School Education, İstanbul Sabahattin Zaim University, İstanbul, Turkey. Email: tuba.boynuegri@izu.edu.tr 3 Department of Guidance and Psychological Counseling. Necmettin Erbakan University, Konya, Turkey. Email: bulentdilmac@gmail.com

Citation: Şimşir, Z., Boynueğri, S. B., Dilmaç, B. (2017). Religion and spirituality in the life of individuals with paraplegia: Spiritual journey from trauma to spiritual development. Spiritual Psychology and Counseling, 2, 89-110. http://dx.doi. org/10.12738/spc.2017.1.0023
} 
People are potentially faced with many traumatic events throughout their lives. Traumatic life events have been examined such as physical assaults or violence; traffic or work accidents; floods, hurricanes, or natural disasters such as earthquakes; surviving war or terrorist events; witnessing injuries or death; life-threatening diseases and lifedamaging injuries (Frans, Rimmö, Aberg \& Fredrikson, 2006; Widom, Dutton, Czaja \& DuMont, 2005). Post-Traumatic Stress Disorder is a category defined in the literature as the group of intense, long-lasting symptoms that occur after an event, sometimes long after (Gelder, Gath, Mayou \& Cowen, 1996). The main clinical features of this diagnosis are extreme agitation after the start of the traumatic event, frequent recollection of related events, and emotional avoidance (American Psychiatric Association, 2007; Taylor, Kuch, Koch, Crockett \& Passey, 1998). After feeling extreme fear, helplessness, or dementia about surviving, a person begins to have difficulty placing their new situation in existing cognitive schemes, questioning their place and meaning in the world; the individual's assumptions that the world is a reliable, predictable place are destroyed (Aker, 2000; Janoff-Bulman \& Berg, 1998; Türkçapar, 2012). Traumatic experiences, on the other hand, can lead to positive changes such as re-questioning the meaning of life, revising one's perceptions of empowerment, redefining priorities, and improving relations (Inci \& Boztepe, 2013; Tedeschi, 1999). Some researchers (Tedeschi, 1999; Tedeschi \& Calhoun, 2004) consider these changes, which can be positive or negative, as an opportunity for personal development. Accordingly, individuals can sometimes even experience the opposite of expected destructive symptoms after a traumatic experience, and this may even force them beyond the limits of the challenge to benefit more effectively from life than they did before the trauma (Janoff-Bulman, 2004; Tedeschi \& Calhoun, 1995).

The positive changes a person experiences following a traumatic situation are defined as perceived benefits, stress-related growth, or post-traumatic growth (Tedeschi, Park \& Calhoun, 1998; Tedeschi \& Calhoun, 2004). According to Tedeschi (1999), the results of reported trauma vary from person to person but tend to enter certain categories: relations with others (primarily points to inter-personal behaviors), new possibilities (indicates changes in goals), increased sense of personal power (implies a change in identity), and spiritual change and life appreciation (refers to a change in certain aspects of the belief system; Tedeschi, Park, \& Calhoun, 1998). Tedeschi and Calhoun (1996) found their scale, the Post Traumatic Growth Inventory, to have five sub-dimensions. Janoff-Bulman's (2004) important study explains what the relationship processes of beliefs, goals, identity, and interpersonal behavior are and how they are formed in order to understand post-traumatic growth. As cited in Tedeschi (1999), changes in basic life goals have been described by Carver and Scheier (1998); McIntosh (1996); and Rothbaum, Weisz, and Snyder (1982). The issue of interpersonal relationships and behaviors has been addressed by many theorists (Tedeschi, 1999). Writers like Nietzsche and Kierkegaard have also 
discussed the role of pain in personal development, although they introduced different interpretive styles. In the 20th century, scientists such as Maslow (1954), Caplan (1964), Frankl (1963), and Yalom (1980) showed that life crises are a path to change. Existential psychologists acknowledge that suffering and stressful experiences are an opportunity for development and define trauma as a time when meaning and courage can be found (as cited in Tedeschi \& Calhoun, 2004).

The concept of post-traumatic growth has been a subject in all teachings since the early ages of human history, questioning the relationship of suffering felt after experiencing an event to the meaning of life. Buddhism, for example, comes from the premise that all existence is suffering and suggests concrete and ultimate ways of escaping from these unbroken lines of suffering that every human being experiences. Like Buddhism, yoga and all other Indian teachings cannot question the normality of suffering in the moment. Suffering is seen as an illusion because the whole universe is seen as an illusion. All other Indian movements that accept Indian beliefs (e.g., Lokayata and Çarvaka schools) have materialist tendencies that suggest that seeking pleasure/rewards and avoiding suffering are the only rational aims of man; they attribute a clear definition of the meaning and function of suffering (Eliade, 1994; Tedeschi \& Calhoun, 1996). In the Mediterranean region of Mesopotamia, the drama of man's torment from the moon to the suffering of Tammuz is associated with the suffering of the gods in many myths. Ancient adaptations and imitations of ancient mysticism on the suffering, death, and resurrection that Tammuz experienced can be seen in the entire world of Eastern Antiquity, and traces of this scenario continue up to and beyond Christianity and post-Christian Gnosticism. One of the greatest advantages of Christianity compared to the old Mediterranean beliefs is said to be how it gives great importance to suffering, transforming it from a painful negative situation into a positive spiritual experience (Eliade, 1994).

According to Islamic belief, the world is a temporary place of trial, and man has been sent to this world for a very short time. After death, each soul is believed to be requited in accordance with justice through the righteousness of Allah. Believing in the afterlife can save one from the anxiety and stress encountered while enabling acceptance of death, as well as giving an individual an idea of what will be gotten in return for the patience one shows to the troubles and obstacles encountered in this world, thereby providing them with a sense of trust, ease, spaciousness, and peace (Cesur, 2012; Hogan \& DeSantis, 1996; Kula, 2004). Apart from beliefs regarding afterlife and forbearance, individuals are presumed to use active and meaningful coping strategies in solving all kinds of problems during prayer where they worship in the personal sense of the self being together with God (Kula, 2004). Vergote (1999) noted that prayer has a positive effect on people's physical and mental health, and on coping with situations that lead to depression. In terms of Islam, prayer and worship 
can be expressed as addressing a request toward God and accepting the supremacy of God by admitting one's weakness in front of God; prayer and worship is interpreted as a way for the soul to ascend toward God, an action of love and adoration toward the Being who creates the wonder and miracle of life (Kula, 2004).

In recent years both in the international arena and in Turkey, many important studies have begun being carried out over the role of beliefs on coping styles in stressful situations (Gorsuch, 1988; Pargament, 1997; Pargament, Koenig \& Perez, 2000; Eryücel, 2013). Pargament and colleagues (Pargament, 1990, 1997; Pargament, Smith, Koenig \& Perez, 1998), who have extensively researched this subject, emphasize that the religious methods used in coping strategies far exceed nonreligious methods of coping, and spirituality is unique from other coping strategies in the sense that it provides results beyond what has been predicted to be good for health and wellbeing. In addition, studies exist that show belief in an afterlife eases adjusting to life post-trauma (Cesur, 2012; Hogan \& DeSantis, 1996). In another study, fulfilling religious practices was found to positively affect people's grieving process (Becker et al., 2007).

The literature shows how important the role of religion and spirituality is for individuals, especially when in crises. For human integrity, the obstacle that suddenly emerges and prevents action in many ways can be regarded among the most difficult situation that one might possibility encounter.

The population of the study consists of paraplegics whose affliction resulted from a sudden accident, and the study was carried out with a group who had never previously participated in any similar research. In fact, although studies on the role of religion and spirituality in the growth of individuals and the disabled who have experienced various trauma exist in the literature, (Hatun, Yavuz-Birben, İnce \& Kalkan-Yeni; 2016; Lee, Park \& Hale, 2016; Shaw, Joseph \& Linley, 2005), no study exists on individuals with spinal cord injuries and their spiritual growth, a sub-dimension of post-traumatic growth (Hatun et al., 2016; Lee et al., 2016; Perera \& Frazier, 2013; Shaw et al., 2015; Williamson, 2014). In this respect, examining the role of religious beliefs in paraplegics' process of coping with traumatic experiences and their changes in religious/spiritual experiences following traumatic experiences becomes important in terms of its contributions both to clinical practices and the literature. The following questions are asked in the survey:

- How have those with spinal cord injuries coped with their traumatic event? What role do religious beliefs play in the post-traumatic growth process?

- What kind of changes occurred in paraplegics' attitudes towards God following their traumatic event? 
- What kind of changes occurred in religious practices following paraplegics' traumatic event?

- What kind of changes occurred in paraplegics' beliefs regarding the concept of an afterlife and fate following their traumatic event?

- What kind of changes occurred in paraplegics' religious participation after their traumatic events?

\section{Method}

\section{Research Model}

The study aims to reveal the effect of religion and spirituality on paraplegics' posttraumatic growth experiences. Furthermore, the kinds of changes in religious and spiritual experiences that these traumatic experiences caused have been examined. For this purpose, the qualitative research method was used. Qualitative research methodology allows gathering in-depth and detailed information on any issue with the participation of a limited number of people. Qualitative research allows for a flexible and holistic approach to investigating human behaviors in the environment from which they emerged (Patton, 2014, Yildirim \& Simsek, 2013). The phenomenological research design was used in this study. Phenomenological research focuses on the experiences individuals have had and how they perceive these experiences (Ersoy, 2016). This research focuses on the experiences of individuals who experienced an accident that resulted in a spinal cord injury and how they make sense of the religious and spiritual changes they experience. For this reason, one can say phenomenology is the most appropriate design for this research.

The research population consists of 15 adults between the ages of 27 and 57 with paralysis resulting from spinal cord trauma. The population group was determined in accordance with the purposive sampling method, a type of sampling widely used in accordance with the qualitative research tradition. Purposive sampling provides rich, in-depth information as opposed to making generalizations (Patton, 2014, Yildirim \& Simsek, 2013). From among the purposive sampling methods, criterion sampling involves selecting cases that meet some predetermined criterion of importance (Yildirim \& Simsek, 2013). The criteria for participants in this study were: to be suffering from paralysis as a result of spinal cord trauma, to be older than 18 , and to have had at least three years pass since their traumatic event happened. The reason for the age limit of 18 is because the study's topic is a philosophical subject that requires a level of cognitive maturity. Indeed, all the scales developed for measuring post-traumatic growth (posttraumatic growth factors, stress-related growth scales, and perceived benefit scales) have been prepared for adults (McMillen \& Fisher, 
1998; Park, Cohen \& Murch, 1996; Tedeschi \& Calhoun, 1996). The reason for the event having happened at least three years prior is the real need for a certain period of growth following the trauma. One should have had time to think about and internalize what they'd experienced in this period (Sarısoy, 2012).

Individual characteristics of the research participants are summarized in Table 1. Participants' names have not been recorded due to ethical issues; coding for male (M43, M36, etc.) and female participants (F56, F37, etc.) indicates gender and age.

Table 1

Participants' Demographic Characteristics

\begin{tabular}{ccccc}
\hline Participant & Gender & Age & $\begin{array}{c}\text { Completed Education } \\
\text { Level }\end{array}$ & $\begin{array}{c}\text { Years Since Event } \\
\text { Occurred }\end{array}$ \\
\hline P1 & Male & 43 & Primary school & 32 \\
P2 & Male & 36 & Middle School & 9 \\
P3 & Male & 45 & Primary school & 26 \\
P4 & Male & 53 & University & 33 \\
P5 & Male & 29 & High school & 5 \\
P6 & Female & 56 & Middle School & 18 \\
P7 & Female & 53 & Primary school & 8 \\
P8 & Male & 54 & Middle School & 6 \\
P9 & Female & 37 & Primary school & 12 \\
P10 & Female & 57 & High school & 11 \\
P11 & Female & 55 & High school & 22 \\
P12 & Male & 53 & Primary school & 11 \\
P13 & Female & 57 & High school & 43 \\
P14 & Male & 27 & High school & 11 \\
P15 & Male & 35 & & 7 \\
\hline
\end{tabular}

\section{Development of the Data Collection Tool}

A semi-structured interview form consisting of open-ended questions was used to investigate the effect of religion and spirituality on the post-traumatic growth experiences of paraplegic individuals in the study. The semi-structured interview allows for both a fixed-choice answer and in-depth response to the relevant area. It is one of the most preferred data collection techniques for qualitative research because of the ease of analysis, its ability to acquire in-depth information when necessary, and those being interviewed can express themself (Büyüköztürk, K1lıç-Çakmak, Akgün, Karadeniz, \& Demirel, 2014).

The researchers developed interview questions in the direction of the research after an extended literature review. Participants' characteristics were taken into account when preparing the questions. The results of the researchers' common decisions were presented to two faculty members with expertise in qualitative research. The final version of the form has been rearranged in accordance with the experts' suggestions. The interview form consists of two parts. In the first part, demographic information such as gender, age, education level and time since the traumatic event occurred are included in Table 1. In the second part, information about what happened, how 
they coped with the situation during and after this process and questions about the changes that took place in religious spiritual life is included in Appendix 1. Because of the limited number of participants, a pilot study was not possible in the process of developing the data collection tool.

\section{Data Collection and Analysis}

In the research process, data were gathered through face-to-face interviews. The interview method is frequently used in phenomenological investigations (Yildirim \& Simsek, 2013). Interviews took place in Istanbul in 2016 at various associations where individuals with spinal cord injuries often go. All interviews were conducted by the researcher who has knowledge and experience with interviewing. The interview process lasted about 2 months. The researcher conducted the research with the participants when they were available, in accordance with the directions of the association's associate director.

All interviews were conducted with people working at the Turkish Spinal Cord Injury Association (TOF) and with people continuing their lives at the center-based nursing homes. Necessary permissions for the interviews were received from the association, and even the association manager provided major support to the work, stating this is the first time such a subject would be studied. Many interviewees also gave similar responses to the questions during the exercises; they stated that they hadn't been asked any questions about changes in their religious or spiritual viewpoints after their traumatic experience, and this made them surprised and happy. Individuals with spinal cord injuries, who had to continue their lives with the same result for very different reasons, were observed to have created a living space for themselves within the association, showing that they are not alone and collaborating with each other over their problems.

Before performing the interviews, information was provided as to the purpose and content of the research. Participants voluntarily participated in the research, and no ethical principles were violated in any way. Interviews were conducted in an environment where participants felt comfortable. Interviews were recorded on a voice recorder with the participants' permission. In addition to using a voice recorder, important points made during the interviews were noted by the researcher. The investigator transcribed the data collected through interviews without making any changes. During transcription, participants who gave inadequate responses were identified and re-interviewed, thus preventing data loss.

Data collected in the study were analyzed using content, analysis a systematic, reproducible technique where certain words of a text are summarized by smaller content categories using specific rule-based coding (Büyüköztürk et al., 2014). The basic process in content analysis is to classify similar data within the framework of 
specific concepts and themes, and to interpret them by arranging them so that the reader can understand (Yildirim \& Simsek, 2013).

Data analysis was performed manually and inductively. First, the researcher studied the transcripts several times to become better acquainted with them. Then, the answers given to each question were read in order; the main ideas and concepts were briefly noted alongside the answers. These were then categorized by coding the data one by one. In the last stage, the representative themes were created to best encapsulate the codes. The researcher was careful to be terse and concise while naming the themes and categories. In the next stage, the analysis was investigated, and necessary corrections were made by another researcher. Three researchers participated in the analysis to reach a common consensus regarding the interpretation. The analysis results were then presented to two faculty members with expertise in qualitative research. Minor changes were made in the direction of the received suggestions, which provided the final form of the analysis.

\section{Findings, Interpretation and Discussion}

In this section, the analytical findings for the data obtained from the interviews with the paraplegics participating in the research are compared with the findings and interpretations from studies in the related literature. The resulting content analysis resulted in five themes: ways of dealing with trauma, changes in attitudes towards God, religious practices, changes in belief in fate and an afterlife, and religious participation. In addition, these themes have been divided into sub-categories.

\section{Ways of Dealing with Trauma}

Post-traumatic growth is not a direct consequence of the traumatic event; it happens as a result of the struggle for surviving and coping with trauma (Linley \& Joseph, 2004; Tedeschi, Calhoun \& Groleau, 2015; Tedecshi \& Calhoun, 2004; Tedeschi, Park, \& Calhoun, 1998). A number of coping methods have been used in the psychology literature for successfully dealing with adverse life events (Tedecshi \& Calhoun, 1995).

Table 2

Ways of Dealing with Trauma

\begin{tabular}{llc}
\hline Theme & Categories & $\begin{array}{c}\text { Number of } \\
\text { participants }\end{array}$ \\
\hline Ways to deal with trauma & Religion as a coping strategy & 2 \\
& Searching for the meaning of life & 1 \\
& Acceptance & 8 \\
& Participating in a paraplegic association and voluntary & 5 \\
& activities & 3 \\
& Social support & 3 \\
\hline
\end{tabular}


As seen in Table 2, the ways participants use to cope with their trauma are categorized as using religion as a coping strategy, searching for the meaning of life, acceptance, participating in volunteer activities and TOF activities and social support.

Two research participants with Islamic beliefs referred to using their religious beliefs for dealing with their trauma. M36 expressed:

Then I seek refuge in God, who can see everything and helps His creatures. You experience this thing between life and death, then a new life here now has started and been presented to me. I am strong. I started fighting, not alone. I started to control everything physically. My biggest success in this has been faith. My point of view changed.

When examining studies in the literature on post-traumatic growth, religion and spirituality are seen to affect the trauma victims' experience of post-traumatic growth (Ai, Peterson, \& Huang, 2003; Calhoun, Cann, Tedeschi, \& McMillan, 2000; Overcash, Calhoun, Cann, \& Tedeschi, 1996; O'Rourke, Tallman, \& Altmaier, 2008). Called religious coping, this process means using one's faith when struggling with stress and problems (Pargament, 2001). Exposure to a traumatic situation, such as a spinal cord injury, which will affect a person's entire life, also requires one to use coping mechanisms throughout life. Hatun et al. (2016) also found that the religious coping style increases disabled individuals' ability to adapt. The way they use religious coping depends on how religion is placed in their life. From this point of view, as few participants used religious coping, the place of religion in participants' lives can be interpreted as being low.

One research participant deals with their trauma by searching for the meaning of life. As an example, M53 expressed:

Life has completely changed for me. I've encountered another world. What I didn't expect was a world I did not design? Hence, I got confused in the first years, of course. It was a life that was not my own. I thought this way, I did. Then I began a life that was not so strange to me in the process. I overcame this it. While I live here in the world, I must have a role in breathing. So I discovered that, after asking, I had to do something like this for those in my life because I also had to experience other events. That helped me get past my injuries.

One factor that explains how and why individuals grow post-trauma is the process of finding meaning (Park \& Ai, 2006). The search for meaning is one of the most frequently addressed questions in the literature regarding the challenges faced by people and post-traumatic growth (Calhoun et al., 2000; Park, Edmondson, Fenster, \& Blank, 2008; Triplett, Tedeschi, Cann, Calhoun, \& Reeve, 2012). According to Frankl (2014), the strength needed for dealing with injury and trauma is to find meaning in one's life. 
Eight of the participants adopted acceptance as a method used for dealing with trauma. M27 expressed:

First I felt disappointed. Then I began the process of accepting shortly after the accident. It took me the first two years. Afterwards I slowly overcame that period. As you see, I'm here today. I'm working.

\section{Similarly, M45 expressed:}

This can happen to you. What God has given ... is there anything to do? There is nothing. It happens any way and we survive somehow. This is God's desire. Nothing can change this. Whatever is written in your destiny, you will live it. There is nothing to be done. In any case, you live with it. I mean, for example, I never thought about other peoples' glances at me or why they asked why I'm like this. Sometimes people talk about your situation... He said don't ask about his story because it makes him unhappy... I never thought in that way. What have I done? This is Allah's will, fate. Nothing can be done once it happens. His life is like this and my life is like this, so.... You accept it as is, somehow. So we go continue our life this way. It's still like this. You are standing against it, but what happens if you stand up?

A person's cognitive processes play a role in post-traumatic growth. The traumatic events people experience lead to a change in existing schema (Valdez \& Lilly, 2015; Tedeschi \& Calhoun, 1995; Tedeschi \& Calhoun, 2004). When a person accepts the reality of an experienced event, acceptance comes to fruition (Tedeschi \& Calhoun, 1995). Pargament (1997) stated that acceptance is one element of religious coping. It seems difficult to get involved in a struggle, to accept the traumatic event or the problem faced if one thinks about the nature of coping with obstacles. Denying what has happened without accepting the present situation is unsustainable in terms of mental health for paraplegics.

For four participants, their role in participating at the TOF and volunteer activities was significant for them in coping with their trauma. F55 expressed:

It is a difficult to have a spinal cord injury and get through that process; you first intensely judge the process. Dear God, why me? This type of questioning occurs too often. But my acute period coincided with the association's foundation. And with all the work I've done in the association, I've inserted myself into the background. I've overcome the situation of asking why me when I'm actively engaged in association activities by helping other disabled individuals. Then I suddenly realize that I have completely overcome the barrier and received the answer to the question because I feel chosen. I'm carrying a flag now. As high as I carry that flag, my next friend should carry it higher than me. This is my test; I am doing my duty in this world.

Participating in volunteer activities at the TOF increases the likelihood of paraplegics being able to cope with a stressful situation. Being together socially with people who are in similar situations makes them feel they are not alone. Thus, they are able to feel better psychologically. 
Three participants in the study were able to deal with their trauma through the social support they received from their familial and social environments. For example, F57 expressed: In this process, my mother has been my greatest support. My parents are 85 years old now. There is fear and concern for what will happen to me and who will look after me.

Sources of social support that provide backing during difficult times can include parents, friends, spouse, lover, family, teachers, neighbors, relatives, and experts (Y1ldirım, 2004; Oktan, 2005). Tedeschi, Park, and Calhoun (1998) emphasized social support as an important variable in post-traumatic growth, indicating that positive changes following the traumatic experience are possible with the presence of supporters. In addition, a number of studies exist in the literature that describe the effect of social support on post-traumatic growth (Bozo, Gündoğdu, \& BüyükasikColak, 2009; Lelorain, Tessier, Florin, \& Bonnaud-Antignac, 2011; Schmidt, Blank, Bellizzi, \& Park, 2012; Prati \& Pietrantoni, 2009).

\section{Change in Attitudes toward God}

The essential feature of religiosity is the cognitive dimension of belief. The strength of peoples' beliefs, whatever they believe in, varies from person to person (Idler, 1999). Traumatic experiences can deeply affect the strength of these beliefs. Individuals can lose faith, as well as become more attached to God in the case of a traumatic experience.

Table 3

Change in Attitudes toward God

\begin{tabular}{llc}
\hline Theme & Categories & Number of participants \\
\hline Change in attitudes toward & Deepening of faith in God & 5 \\
God & Feeling closer to God & 7 \\
& Believing that God is bountiful & 2 \\
& Feeling distanced from God & 1 \\
\hline
\end{tabular}

The changes in attitudes toward God that took place in the participants' lives is shown in Table 3. These have been categorized as deepening of faith in God, feeling closer to God, believing that God is bountiful, and feeling distanced from God. Four participants stated no change in their attitudes toward God.

Five research participants stated a change in their attitudes toward God as a deepening of their faith in God. For example, M45 stated:

I've always had faith in God. My faith has become even stronger. So it can change. You seek refuge in God.

Seven research participants showed their change in attitudes towards God as feeling closer to God. For example, M29 stated: 
Commitment ... At least I was not alone ... For example, if there is no one in my life ... You are clinging more solidly to life. This is also mentioned in Quran too, you are alone in the room but actually not alone by yourself. I learned that; I put one more dish when I sit at the table. Even if I am the only one, I always have a guest. You're not alone, because if God created me, He did it for a reason. He's always with you if He created you.

Similarly, M36 said:

I am very close to my Lord. Yes, I nag Him and ask things of Him. God who gives and takes away commands that we should pray to Him. I offer my wishes for my sake, wanting while ashamed. I talk. I know I'm not alone. The greatest thing that has been given to me is being blessed in this life to have seen holy places and the Ka'bah in order to amend my mistakes at this young age. Thank goodness you will not leave this path. Thanks be to the Lord and guide us on the straight path. Everyone can take this road. He has preordained this path for everyone.

Two research participants' changes in attitudes are a way of believing that God is bountiful. M27 stated:

So I see this situation as a grace. I think that I am God's beloved one. I feel that He has provided me with difficulty but has not forgotten me.

Another research participant began to feel more distant from God after their event. M53 stated:

Even though my point of view towards the Creator has not changed, I feel far away from Him.

Survey results show that most of the participants' attitudes toward God have changed positively. Although participants have difficult living conditions, they feel closer to God and live more faithfully. Lawrence (1997) developed the God Image Inventory (GII) to investigate individuals' relationship with God and their image of God. The scale consists of the following sub-dimensions: presence, challenge, acceptance, benevolence, influence, providence, faith and salience. In Lee et al. (2016) study of 245 university students who had experienced a traumatic event, significant positive correlations exist between the number of traumatic events and their view of God from the subscales of religion and spirituality. After experiencing trauma, people sometimes more rigidly cling to God, religion, and belief; sometimes they can move away from or even change their faith. The majority of research participants having positive changes in their attitudes toward God might result from their religious beliefs (Islam), their faith in the concept of trials mentioned in the Qur'an, and their knowledge of parables and stories regarding the tribulations of the prophets. Another reason for this could be that their mental image of God has positive attributes; they see God as forgiving, compassionate, bounteous, and close to His servants. 


\section{Religious Practices}

One of the sources that people first resort and relate to when facing negative living conditions is their religious beliefs. In such cases, the first religious activity is prayer and asking for help from the creator. Werdel and Wicks (2012) stated that the most commonly used in the literature on post-traumatic growth religious practice is prayer. Religious practices usually consist of watching religious television programs or listening to religious radio programs, reading sacred books or other religious texts, contributing to religious institutions, and seeking forgiveness (Fellow \& Maryland, 1999).

Table 4

Religious Practices

\begin{tabular}{llc}
\hline Theme & Categories & $\begin{array}{c}\text { Number of } \\
\text { participants }\end{array}$ \\
\hline Religious Practices & Making daily worship more regular and frequent & 54 \\
& Reading religious books & 1 \\
& Performing new religious practices & 4 \\
& Decrease in worship & \\
\hline
\end{tabular}

As shown in Table 4, the theme of religious practice, which is one of the changes in the participants' lives, is categorized as performing daily worship more regularly and frequently, reading religious books, performing new religious practices, and decreasing worship. Four research participants stated no change in their religious practice.

The change in religious practices for five research participants was to perform daily worship more regularly and frequently. For example, M54 stated:Of course we were praying, but not regularly. That was really the case. But now I pray 5 times a day.

The change in religious practices for one of the persons participating in the research was to read religious books. M53 expressed:

In other words, I began to observe the worship of many people in a universal sense, reading publications and sources. But as I was searching for the reality of what Allah considers decent as a Muslim, my Muslim identity had already been consolidated.

The change in religious practices for four research participants was to perform new religious practices. For example, F53 stated:

My father was an atheist and raised us this way. I started believing in God before the accident. I didn't know I wasn't worshipping. Now I pray a lot; I participate in Qur'an courses.

One participant's change in religious practices is doing less worship than before. For example, M53 stated, "I used to go to Friday prayers and I fasted. After the illness, it was difficult and I stopped doing these things." 
Religious practices of some participants in the study increased while others' religious practices decreased or had no change. This can be a consequence of a change in beliefs and attitudes towards God after the trauma. The increase in the attachment of people to God and religion can lead to an increase in religious practices. Studies exist in the literature that show the relationship between post-traumatic growth and religious-spiritual practices.

The post-traumatic growth levels of the older participants performing religious practices more were found to be higher in the study of Cadell, Regehr, and Hemsworth (2003), conducted with 174 participants who had lost their relatives because of AIDS. Levine, Aviv, Yoo, Ewing, and $\mathrm{Au}$ (2009) found that $81 \%$ of women perform religious practices in a mixed designed (qualitative and quantitative) study conducted over 174 women with breast cancer. The research found that the levels of post-traumatic growth were higher in women who worshipped more.

\section{Changes in Belief in Fate and an Afterlife}

As shown in Table 5, one of the changes in the lives of the participants is in their belief in fate and an afterlife; this theme can be sub-categorized as forming belief in fate and an afterlife, better understanding of fate and the afterlife, and an increase in thoughts of death. Nine of the participants stated no change in their belief in fate and an afterlife.

Table 5

Belief in the Afterlife and Fate

\begin{tabular}{llc}
\hline Theme & Categories & Number of participants \\
\hline Changes in Belief in the & Forming belief in fate and the afterlife & 1 \\
Afterlife and Fate & Better understanding of fate and the afterlife & 3 \\
& Thinking more about death & 1 \\
\hline
\end{tabular}

One participant's change belongs to the sub-theme of forming belief in fate and an afterlife. F53 expressed,

I began to believe in Allah after the accident. Fate and the Hereafter were later formed in my faith.

Three research participants' changes belong to the sub-theme of better understanding of fate and the afterlife.

For example, F37 expressed:

I thought about whether I could have changed fate. Because God offers preliminary opportunities. Let's say we have 2 options: It's up to us to do it, or it's our own will. We choose one, but do we know the result? We don't know. Can we see? No, we don't know whether the result will be good or bad. Our destiny is shaped by that decision. I wish I could have chosen another way, and I asked myself, "Could I have made a difference?" I think about it. Let's say I didn't fall from the balcony. Would it have happened again if the car 
had hit me on the road? If I experience it and this happens, than this means it is my destiny and I live a disabled life. I always think logically.

One research participant's change in belief belongs to the sub-theme of thinking more about death. M27 stated:

I started thinking more about death.

Faith in fate and the hereafter are among the elements of being religious (Rohrbaugh \& Jessor, 1975). While the research results show some paraplegics have changed their beliefs in fate and the hereafter, the majority stated no change in beliefs on fate and the hereafter. Similarly, Lee et al. (2016) study of 245 university students investigating the relationships among being exposed to trauma with religiosity and spirituality showed that being exposed to a traumatic event is not associated with one's belief in the hereafter, which is one of the sub-dimensions of religiosity and spirituality.

Belief in an afterlife and fate is one of the most debated topics among clergymen and occupies most peoples' minds, whatever they believe in. Therefore, experiencing such trauma can also affect these beliefs. As can be seen, five participants changed their beliefs in the afterlife and fate. Even one participant who had been an atheist in the past formed a belief in the hereafter and fate.

\section{Religious Involvement}

As shown in Table 6, one of the changes in the lives of the participants is spiritual involvement; this can be categorized in three sub-themes: failing to attend due to physical disability, receiving religious education, and going to the mosque. Five participants said they had never participated in activities of religious organizations.

Table 6

Religious Involvement

\begin{tabular}{llc}
\hline Theme & Categories & Number of participants \\
\hline Religious Involvement & Failing to attend due to physical disability & 4 \\
& Receiving religious education & 4 \\
& Going to the mosque & 2 \\
\hline
\end{tabular}

Four research participants stated being unable to participate in religious practices because of their physical disability. For example, F55 expressed:

We usually cannot enter mosques, but we can comfortably do this abroad because there are ramps. We do not have this in our mosques. We have lost many friends. We could only see their funeral from very far. We couldn't ascend the stairs to where we were going. I mean, we cannot reach many places, but everywhere belongs to God and I worship here, I feel like I go to Friday prayer.

Four research participants started receiving religious education. For example, F57 described, 
Here again we have religious education. We have memorized what we have altogether forgotten. Normally I cannot go to courses or anything. We took the course here.

Two research participants stated going to mosques for religious involvement. For example, M45 expressed:

After the accident I went to Friday prayer. I even go in the village. In the village, also ... we have some problems because we have discomfort... Because you are like that, your prayers will not be accepted ... There are rumors like this, okay? For example, one day (I couldn't believe this) I went to the mosque and I asked an instructor about having these troubles, I asked the mosque's leader, ok? Some people say that my prayers are not acceptable. If you come to the mosque your prayers will not be accepted. "There is no such thing," he said. "Allah is testing you with this. Never think about anything in your life like that; you are accepted with your imperfections," he said. "Worship how you want," he said, "There is no such thing. Don't worry about what other people say." So I went on like that.

According to the research results, some of the paraplegic participants do not participate religiously because of their physical disability, while others do. Religious participation is a concept with both attitudinal and behavioral dimensions. Religious participation mostly involves official religious institutions such as mosques, churches, synagogues, temples, ashrams, and so on (Idler, 1999). Religious participation, a dimension of religiosity, is associated with post-traumatic growth (Pargament, 1997; Tedeschi \& Calhoun, 1995). One seeks religious activity in the post-traumatic growth process. Moreover, religious participation triggers people's spiritual maturity of the people (Tedeschi \& Calhoun, 1996). Religious participation also affects subjective psychological well-being. Greenfield and Marx's (2007) study conducted with 3,032 adults aged between 25 and 74 years old shows that more participation in religious institutions positively affect and increased life satisfaction.

Although some participants were unable to engage in religious participation because of being physically disabled, other participants increased their participation in religious activities. One can say that when religious participation is considered as a requirement of religious belief, individuals who show positive changes in their attitudes toward God show an increase in participation in religious activities.

\section{Conclusions and Recommendations}

The aim of this research is to reveal the effect of paraplegics' religious and spiritual tendencies on their post-traumatic growth. Moreover, the research aims to reveal the changes that occur in their religious and spiritual experiences, a sub-dimension of post-traumatic growth for individuals. Five themes emerged from analyzing the interviews performed with 15 individuals with spinal cord injuries: strategies for coping with trauma, changes in attitudes towards God, religious practices, changes in belief in fate and an afterlife, and religious participation. Additionally, these 
themes have been divided into sub-categories. Strategies for coping with trauma is sub-categorized as religious coping, exploring the meaning of life, acceptance, participating in volunteer activities at the Spinal Cord Injury Association, and social support. The theme of religious practice has been sub-categorized as performing daily worship more regularly and frequently, reading religious books, performing new religious practices, and decreasing worship. The theme of changes in belief in the hereafter and fate have been sub-categorized as forming a belief in fate and an afterlife, better understanding fate and the hereafter, and an increase in thoughts about death. The theme of religious participation has been sub-categorized as failing to attend religious services due to physical disability, receiving a religious education, and going to the mosque.

The study shows that some paraplegics benefit from religious beliefs during the process of coping, and these beliefs affect their post-traumatic growth process. Moreover, their traumatic experience has led to visible changes in participants' religious and spiritual feelings, as well as their religious practices. Most of these changes are also positive in this respect. These changes demonstrate that participants have experienced post-traumatic growth.

This research is limited in that no plot study was done before giving the final form of the interview. Another limitation is that data were gathered only through the interview method, and the research was carried out over a limited number of participants. Moreover, we do not know how individuals with different religious beliefs and traumas cope with this process, nor do we know what kind of changes have occurred in their religious/spiritual lives at the end of the process because all research participants in this study are Muslim.

Considering the research results and limitations, the following proposals can be listed. In order to better demonstrate the effect of religious and spiritual tendencies on the post-traumatic growth process and to better understand the changes that occur in peoples religious and spiritual lives post trauma, researchers should study individuals with different traumatic experiences and in larger numbers. Furthermore, as conducting qualitative research based solely on the interview method is insufficient, carrying out a mixed research design that includes quantitative approaches could be useful. As only a small number of participants claimed to benefit from their religious beliefs in order to cope with their trauma, new research is needed to examine the role of religion in post-traumatic growth. Researchers working in this field may be able to make significant contributions to the literature by working with people who experienced different traumas. In terms of clinical practices, the ways in which psychologists and counselors take religious and spiritual resources into account and support using them for counselees to benefit from these sources could be beneficial 
in terms of increasing counselees' well-being in the counseling individuals with traumatic experiences. The concept of post-traumatic growth, which is also focused on through positive psychology, can be achieved by emphasizing the positive changes that clients have undergone without ignoring it in the therapy and counseling sessions by drawing clients' attention to these changes. Religious and spiritual changes, one of the dimensions of this change, can be greater emphasized to the clients who place importance on religion in their lives. While individuals with spinal cord injuries are thought to have to come to the hospital for a long time for treating their physical disability, during this time, physical therapy, in addition to providing spiritual counseling and guidance, may be beneficial both in terms of physical and mental health. Research on the influence of people in paraplegics' surroundings on changes in these paraplegics' religion and spirituality posttrauma can guide consultants who work in this field.

\section{References}

Ai, A. L., Peterson, C., \& Huang, B. (2003). Research: The effect of religious-spiritual coping on positive attitudes of adult Muslim refugees from Kosovo and Bosnia. The International Journal for the Psychology of Religion, 13(1), 29-47.

Aker, A. T. (2000). Temel sağllk hizmetlerinde psikososyal travmaya yaklaşım [Approach to psychosocial trauma in primary health care services]. İstanbul, Turkey: Mutlu Doğan Ofset U. V. Lak Tesisleri.

American Psychiatric Association. (2007). Ruhsal bozuklukların tanısal ve sayımsal el kitabı (DSM-4) [Diagnostic and statistical manual of mental disorders: DSM-4] (E. Köroğlu, Trans.). Ankara, Turkey: Hekimler Yayın Birliği.

Becker, G., Xander, C. J., Blum, H. E., Lutterbach, J., Momm, F., Gysels, M., \& Higginson, I. J. (2007). Do religious or spiritual beliefs influence bereavement? A systematic review. Palliative Medicine, 21, 207-217.

Bozo, O., Gündogdü, E., \& Büyükasik-Colak, C. (2009). The moderating role of different sources of perceived social support on the dispositional optimism-posttraumatic growth relationship in postoperative breast cancer patients. Journal of Health Psychology, 14(7), 1009-1020.

Büyüköztürk, S., Kilic-Cakmak, E., Akgün, O. E., Karadeniz, S., \& Demirel, F. (2014). Bilimsel araştırma yöntemleri [Scientific research methods] (17th ed.). Ankara, Turkey: Pegem.

Cadell, S., Regehr, C., \& Hemsworth, D. (2003). Factors contributing to post-traumatic growth: A proposed structural equation model. American Journal of Orthopsychiatry, 73(3), 279-287.

Calhoun, L. G., \& Tedeschi, R. G. (2004). The foundations of posttraumatic growth: New considerations. Psychological Inquiry, 15(1), 93-102.

Calhoun, L. G., Cann, A., Tedeschi, R. G., \& McMillan, J. (2000). A correlational test of the relationship between posttraumatic growth, religion and cognitive processing. Journal of Traumatic Stress, 13(3), 521-527.

Cesur, G. (2012). Yetişkinlerde travmatik yasın ve travma sonrası büyümenin psikososyal belirleyicileri. (Unpublished master's thesis). Hacettepe University, Ankara, Turkey. Retrieved from https://tez.yok.gov.tr/UlusalTezMerkezi 
Eliade, M. (1994). Ebedi dönüş mitosu [Eternal return myth] (U. Altuğ, Trans.). Ankara, Turkey: İmge Kitabevi.

Ersoy, F. (2016). Fenomenoloji [Phenomenology]. In A. Saban \& A. Ersoy (Eds.), Eğitimde nitel araştırma desenleri [Qualitative research designs in education]. Ankara, Turkey: Anı Yayınc1lık.

Eryücel, S. (2013). Yaşam olayları ve dini başa çıkma [Life events and religious achievement]. Mustafa Kemal Üniversitesi Sosyal Bilimler Enstitüsü Dergisi, 10(23), 251-271.

Fellow, L., \& Maryland, R. (1999). Private religious practices in multi-dimensional measurement of religiousness/spirituality for use in health research: A report of the Fetzer Institute/National Institute on aging working groups (pp. 39-42). Kalamazoo, MI: Fetzer Institute.

Frankl, E. V. (2014). İnsanın Anlam Arayışı [Man’s search for meaning] (S. Budak, Trans.). İstanbul, Turkey: Okyanus Yayıncılı.

Frans, Ö., Rimmö, P. A., Aberg, P., \& Fredrikson, M. (2006). Trauma exposure and post-traumatic stress disorder in the general population. Acta Psychiatrica Scansinavica, 111, 291-299.

Gelder, M., Gath, D., Mayou, R., \& Cowen, P. (1996). Child psychiatry. Oxford Textbook of Psychiatry, 761-825.

Gorsuch, R. L. (1988). Psychology of religion. Annual Review of Psychology, 39(1), 201-221.

Greenfield, E. A., \& Marks, N. F. (2007). Religious social identity as an explanatory factor for associations between more frequent formal religious participation and psychological wellbeing. The International Journal for the Psychology of Religion, 17(3), 245-259.

Hatun, O., Yavuz-Birben, F., İnce, Z., \& Kalkan-Yeni, G. (2016). The ticket to heaven: A spiritual resource for coping with disability. Spiritual Psychology and Counseling, 1(2), 209-235.

Hogan, N., \& DeSantis, L. (1996). Continuing Bonds: New Understandings of Grief (pp. 235-254). New Delh, India: Taylor and Francis.

Idler, E. (1999). Organizational religiousness. In Multidimensional Measurement of Religiousness/ Spirituality for use in health research: A report of the Fetzer Institute/ National Institute on Aging (pp. 75-80). Kalamazoo, MI: Fetzer Institute.

Inci, F., \& Boztepe, H., (2013). Travma sonrası büyüme: Öldürmeyen acı güçlendirir mi? [Post traumatic growth: Does the pain that doesn't kill strengthen?]. Psikiyatri Hemşireliği Dergisi, 4(2), 80-84.

Janoff-Bulman, R. (2004). Posttraumatic growth: Three explanatory models. Psychological Inquiry, 15(1), 30-34.

Janoff-Bulman, R., \& Berg, M. (1998). Disillusionment and the creation of value: From traumatic loss to existential gains. In J. Harvey (Ed.), Perspectives on loss: A sourcebook. Washington, DC: Taylor \& Francis.

Kula, N. (2004). Gençlerde ızdırap tecrübesine bağlı dini krizle başa çıkmaya yönelik öneriler [Suggestions for successful religious crisis relating to experience of displeasure in youth]. İstanbul, Turkey: İSAV.

Lawrence, R. T. (1997). Measuring the image of God: The God image inventory and the God image scales. Journal of Psychology and Theology, 25(2), 214-226.

Lee, S. Y., Park, C. L., \& Hale, A. E. (2016). Relations of trauma exposure with current religiousness and spirituality. Mental Health, Religion \& Culture, 19(6), 493-505.

Lelorain, S.,Tessier, P., Florin, A., \& Bonnaud-Antignac, A. (2011). Post-traumatic growth in long term breast cancer survivors: Relation to coping, social support and cognitive processing. Journal of Health Psychology, 17(5), 627-639. 
Levine, E. G., Aviv, C., Yoo, G., Ewing, C., \& Au, A. (2009). The benefits of prayer on mood and well-being of breast cancer survivors. Supportive Care in Cancer, 17(3), 295-306.

Linley, P. A., \& Joseph, S. (2004). Positive change following trauma and adversity: A review. Journal of Traumatic Stress, 17(1), 11-21.

McMillen, J. C., \& Fisher, R. H. (1998). The Perceived Benefit Scale: Measuring perceived positive life changes after negative events. Social Work Research, 22(3), 173-187.

O'Rourke, J. J., Tallman, B. A., \& Altmaier, E. M. (2008). Measuring post-traumatic changes in spirituality/religiosity. Mental Health, Religion and Culture, 11(7), 719-728.

Oktan, V. (2005). Yalnızlık ve algılanan sosyal destek düzeyinin ergenlerdeki öfkenin gelişimine etkisi [The effect of loneliness and perceived social support level on the development of anger in adolescents]. Marmara Üniversitesi Atatürk Eğitim Fakültesi Eğitim Bilimleri Dergisi, 21, 183-192.

Overcash, W. S., Calhoun, L. G., Cann, A., \& Tedeschi, R. G. (1996). Coping with crises: An examination of the impact of traumatic events on religious beliefs. The Journal of Genetic Psychology, 157(4), 455-464.

Pargament, K. I. (1990). God help me: Toward a theoretical framework of coping for the psychology of religion. Research in the Social Scientific Study of Religion, 2, 195-224.

Pargament, K. I. (1997). The psychology of religion and coping. New York, NY: Guilford Press.

Pargament, K. I. (2001). The psychology of religion and coping: Theory, research, practice. New York, NY: Guilford Press.

Pargament, K. I., Smith, B. W., Koenig, H. G., \& Perez, L. (1998). Patterns of positive and negative religious coping with major life stressors. Journal for the Scientific Study of Religion, 37, $710-724$.

Park, C. L., \& Ai, A. L. (2006). Meaning making and growth: New directions for research on survivors of trauma. Journal of Loss and Trauma, 11(5), 389-407.

Park, C. L., Cohen, L. H., \& Murch, R. L. (1996). Assessment and prediction of stress-related growth. Journal of Personality, 64, 71-105.

Park, C. L., Edmondson, D., Fenster, J. R., \& Blank, T. O. (2008). Meaning making and psychological adjustment following cancer: The mediating roles of growth, life meaning, and restored justworld beliefs. Journal of Consulting and Clinical Psychology, 76(5), 863.

Patton, M. Q. (2014). Nitel araştırma ve değerlendirme yöntemleri [Qualitative research and evaluation methods] (M. Bütün, \& B. Demir, Trans.). Ankara. Turkey: Pegem Akademi Yayıncilik.

Perera, S., \& Frazier, P. A. (2013). Changes in religiosity and spirituality following potentially traumatic events. Counselling Psychology Quarterly, 26(1), 26-38.

Prati, G., \& Pietrantoni, L. (2009). Optimism, social support, and coping strategies as factors contributing to posttraumatic growth: A meta-analysis. Journal of Loss and Trauma, 14(5), 364-388.

Rohrbaugh, J., \& Jessor, R. (1975). Religiosity in youth: A personal control against deviant behavior. Journal of Personality, 43(1), 136-155.

Sarisoy, G. (2012). An investigation of post-traumatic growth rate and factors that predict posttraumatic growth in breast cancer patients (Unpublished master's thesis). Hacattepe University, Istanbul, Turkey. Retreived from https://tez.yok.gov.tr/UlusalTezMerkezi 
Schmidt, S. D., Blank, T. O., Bellizzi, K. M., \& Park, C. L. (2012). The relationship of coping strategies, social support, and attachment style with posttraumatic growth in cancer survivors. Journal of Health Psychology, 17(7), 1033-1040.

Shaw, A., Joseph, S., \& Linley, P. A. (2005). Religion, spirituality, and posttraumatic growth: A systematic review. Mental Health, Religion \& Culture, 8(1), 1-11.

Taylor, S., Kuch, K., Koch, W. J., Crockett, D. J., \& Passey, G. (1998). The structure of posttraumatic stres symptoms. Journal of Abnormal Psychology, 107, 154-160.

Tedeschi, R. G., \& Calhoun L. G. (1996). The posttraumatic growth inventory: Measuring the positive legacy of trauma. Journal of Traumatic Stress, 9, 455-471.

Tedeschi, R. G. (1999). Violence transformed: Post-traumatic growth in survivors and their societies. Aggression and Violent Behavior, 4(3), 319-341.

Tedeschi, R. G., \& Calhoun, L. G. (1995). Trauma and transformation. London, UK: Sage Publications.

Tedeschi, R. G., \& Calhoun, L. G. (2004). Posttraumatic growth: Conceptual foundations and empirical evidence. Psychological Inquiry, 15(1), 1-18.

Tedeschi, R. G., Calhoun, L. G., \& Groleau, J. M. (2015). Clinical applications of post-traumatic growth. Positive psychology in practice: Promoting human flourishing in work, health, education, and everyday life (pp. 503-518). New York, NY: John Wiley and Sons.

Tedeschi, R. G., Park, C. L., \& Calhoun, L. G. (Eds.). (1998). Posttraumatic growth: Positive changes in the aftermath of crisis (pp. 1-23). Mahwah, NJ: Lawrence Erlbaum Associates.

Triplett, K. N., Tedeschi, R. G., Cann, A., Calhoun, L. G., \& Reeve, C. L. (2012). Post-traumatic growth, meaning in life, and life satisfaction in response to trauma. Psychological Trauma: Theory, Research, Practice, and Policy, 4(4), 400.

Türkçapar, H. (2012). Bilişsel Terapi [Cognitive Therapy]. Ankara, Turkey: Hyb Yayıncılık.

Valdez, C. E., \& Lilly, M. M. (2015). Posttraumatic growth in survivors of intimate partner violence: An assumptive world process. Journal of Interpersonal Violence, 30(2), 215-231.

Vergote, A. (1999). Din, inanç ve inançsızlık [Religion, belief and disbelief] (V. Uysal, Trans.). İstanbul, Turkey: MUİ Yayınları.

Werdel, B. M., \& Wicks, J. W. (2012). Primer on posttraumatic growth. New Jersey, NY: John Wiley.

Widom, C. S., Dutton, M. A., Czaja, S. J., \& DuMont, K. A. (2005). Development and validation of a new instrument to assess lifetime trauma and victimization history. Journal of Traumatic Stress, 18(5), 519-532.

Williamson, C. (2014). Post-traumatic growth and religion in Rwanda: Individual well-being, collective false consciousness. Mental Health, Religion \& Culture, 17(9), 946-955.

Yildirim, A., \& Simsek, H. (2013). Sosyal bilimlerde bilimsel araştırma yöntemleri [Scientific research methods in social sciences]. Ankara, Turkey: Seçkin Yayıncılık.

Yıldırım, İ. (2004). Eş destek ölçeğinin geliştirilmesi [Development of the Co-Support Scale]. Türk Psikolojik Danışma ve Rehberlik Dergisi, 3(22), 19-26. 


\section{APPENDIX 1}

1. Introduction:
a. Age
b. Gender
c. Education status
d. Job

2. How long has it been since you were first paralyzed?

3. How did you cope with the pain that you experienced? How did you struggle with it? What are the things that help you to cope with?

4. What kind of changes do you have in your feelings, thoughts, and beliefs about God after your trauma?

5. What kind of changes have you experienced in your everyday spiritual experiences following your trauma (your worship, daily religious practices, etc.)?

6. What kind of changes have you experienced in your belief in the hereafter and fate following your trauma (e.g., acceptance, thinking or not thinking about the afterlife, increase or decrease in thinking about these kinds of matters)?

7. What kind of changes has happened to your activities such as going to the mosque or participating in religious organizations following your traumatic experience? 